Review Article

\title{
Role of Janus Kinase (JAK) Inhibitor in Autoimmune Ocular Inflammation: A Systematic Review
}

\author{
Ji Wen, ${ }^{1}$ Huifang Hu, ${ }^{1}$ Menglin Chen, ${ }^{2}$ Hang Yang, ${ }^{1}$ Yi Zhao, ${ }^{1}$ and Yi Liu $\mathbb{D}^{1}$ \\ ${ }^{1}$ Department of Rheumatology and Immunology, West China Hospital, Sichuan University, Chengdu, Sichuan, China \\ ${ }^{2}$ Department of Occupational Health and Toxicity/Nephrology, West China Fourth Hospital, Sichuan University, Chengdu, \\ Sichuan, China
}

Correspondence should be addressed to Yi Liu; yi2006liu@163.com

Received 9 April 2021; Revised 9 July 2021; Accepted 19 November 2021; Published 20 December 2021

Academic Editor: Chiara Posarelli

Copyright (c) 2021 Ji Wen et al. This is an open access article distributed under the Creative Commons Attribution License, which permits unrestricted use, distribution, and reproduction in any medium, provided the original work is properly cited.

Purpose. To evaluate the effectiveness of Janus kinase (JAK) inhibitors for the treatment of patients with autoimmune disease and associated inflammatory ocular diseases. Methods. We identified relevant literature by screening the MEDLINE, PubMed, and Cochrane databases for randomized controlled trials, cohort studies, case controls, and case reports. Results. Seven studies, including 11 patients, were included in the final systematic analysis. Of the 11 patients, there were 5 cases of juvenile idiopathic arthritis- (JIA-) associated uveitis, 1 case of rheumatoid arthritis- (RA-) associated keratitis, 1 case of RA-associated scleritis, 1 case of psoriasis-associated conjunctivitis, 2 cases of noninfectious scleritis, and 1 case of uveitis with suspected autoimmune disease. None of these 11 patients responded adequately to conventional treatments, including biological agents; these were all refractory cases and switched to JAK inhibitor therapy. Irrespective of whether they were suffering from uveitis, scleritis, or other types of ocular inflammation, all 11 patients showed an improvement to JAK inhibitors without significant side effects. Different types of JAK inhibitors might be associated with different responses when used to treat ocular inflammation. Conclusions. JAK inhibitors may represent an alternative treatment option for patients with autoimmune ocular inflammation.

\section{Introduction}

Noninfectious inflammatory ocular diseases can occur in isolation or in the context of systemic autoimmune diseases, such as rheumatoid arthritis (RA), juvenile idiopathic arthritis (JIA), ankylosing spondylitis (AS), and systemic vasculitis (SV). Ocular inflammation includes a diverse group of ocular inflammatory diseases that frequently present in the form of scleritis, keratitis, uveitis, conjunctivitis, and retinitis; these conditions can lead to a number of other visionthreatening ocular complications.

Currently, the traditional treatments for such ocular complications are nonsteroidal anti-inflammatory drugs (NSAIDs), corticosteroids, and conventional diseasemodifying antirheumatic drugs (cDMARDs) [1]. However, some patients are nonresponsive to such therapies. Several classes of biological agents have been reported to control ocular inflammation, including TNF-alpha blockers, tocilizumab, and rituximab [2-5]. However, the literature also reports that some severe cases were refractory and failed to reach remission $[2,3]$.

The Janus kinase (JAK) pathway plays a key role in inflammatory cell regulation, cytokine production, and proinflammatory signal transduction $[6,7]$. Dysregulation of the JAK pathway is associated with the pathogenesis of various inflammatory and autoimmune disorders. Therefore, JAK inhibitors have the potential to alleviate the inflammatory process. However, the applications of JAK inhibitors are relatively new in terms of clinical therapy, particularly for autoimmune diseases. Study data is not abundantly available for this particularly field-of-interest. In this study, we aimed to summarize and analyze existing evidence related to the efficacy of different JAK inhibitors with regard to controlling ocular inflammation. 


\section{Methods}

2.1. Inclusion and Exclusion Criteria. We conducted a retrospective and systematic evaluation of patients with noninfectious inflammatory ocular diseases who were treated with JAK inhibitors. We examined a range of literature types, including randomized controlled trials, cohort studies, and case reports. These articles involved a range of inflammatory ocular diseases, including uveitis, scleritis, keratitis, conjunctivitis, and retinitis. During our literature searches, we defined JAK inhibitors as tofacitinib, baricitinib, jakinib, ruxolitinib, and filgotinib.

Articles were excluded if any infectious pathogen was involved. We also excluded research involving animal experiments and literature that had been duplicated, was incomplete, or contained obvious errors.

2.2. Search Strategy. Literature searches were carried out by two independent investigators. The investigators screened the MEDLINE, PubMed, and Cochrane databases for relevant articles that were published from inception to March 2021. The search algorithm included several keywords connected by Boolean operator reported to control ocular inflammation. First, the keywords "Janus Kinase inhibitor", "JAK inhibitor”, “tofacitinib”, "baricitinib”, “jakinib”, “ruxolitinib" and "filgotinib" were connected by the Boolean operator "OR". Next, the keywords "ocular inflammation", "episcleritis", "scleritis", "uveitis", "keratitis", "conjunctivitis", "retinal vasculitis", and "retinitis" were connected by the Boolean operator "OR". Finally, these search results were connected by the Boolean operator "AND". Two investigators independently searched and assessed the published studies. Any disagreement was resolved by consensus.

2.3. Statistical Analysis. We retrospectively collated a range of demographic, clinical, and therapeutic data, including authors, publication date, country of origin, gender, age, disease duration, diagnoses, complications, previous therapy history, and treatment outcomes. Data were analyzed using IBM SPSS Statistics for Windows, version 24. For quantitative variables, we calculated the mean and standard deviation.

\section{Results}

3.1. Study Selection and Features. A total of 63 articles were separately identified from MEDLINE, PubMed, and Cochrane databases. Figure 1 provides flow diagram showing the process used to review the literature. All the identified articles were case reports; our literature searches did not identify any relevant randomized controlled trials, cohort studies, or cross-sectional surveys. The earliest case report was published in 2014. A total of 7 articles reported the therapeutic effects of JAK inhibitors when used to treat ocular inflammation; 11 patients were included [8-14]. The basic features of all included articles are summarized in Table 1.

3.2. Demographic and Clinical Features of Patients. We identified 11 patients who previously presented with ocular inflammation and received therapeutic management involv- ing JAK inhibitors. Of the 11 patients, 5 (45.45\%) had JIAassociated uveitis [11, 12], 1 (9.09\%) had RA-associated keratitis [8], 1 (9.09\%) had RA-associated scleritis [14], 1 (9.09\%) had psoriasis-associated conjunctivitis [9], 2 (18.18\%) had noninfectious scleritis, and 1 (9.09\%) had uveitis with suspected autoimmune disease [10, 13] (Table 1). According to the classification proposed by the Standardization of Uveitis Nomenclature (SUN) Working Group [15], there were 6 patients with uveitis including 2 cases of anterior uveitis (33.33\%), 3 cases of panuveitis (50.00\%), and 1 case of anterior uveitis and intermediate uveitis (16.67\%). These patients suffered from the abovementioned inflammations of ocular tissue and even had complications including macular edema, retinal detachment, cataract, band keratopathy, and glaucoma. In these articles, there were 3 males and 8 females whose mean age and mean disease duration were, respectively, $39.82 \pm 14.94$ years (range: 18-65 years) and $16.13 \pm 12.18$ years (range: $2-34$ years) (Table 2 ).

3.3. Previous Therapeutic Histories. Some of the identified patients received therapies involving conventional DMARDs. All patients had a long-term history of ocular inflammation, received complicated therapies, and were unable to achieve a long-term and stable resolution. Monotherapy involving conventional DMARDs was commonly reported to be ineffective. Even in combined therapeutic approaches, most of the identified patients failed to show adequate improvement; some even presented with obvious side effects (Table 3).

Our literature search revealed that biological inhibitors only provided temporary relief (Table 4). These patients experienced frequent flares of systemic symptoms and ocular symptoms. Most of the patients were treated with combined therapeutic approach involving multiple forms of steroids including 6 patients treated with prednisone, 1 patient treated with methylprednisolone, and 1 patient treated with dexamethasone. Three of them completely received the local injection and the topical and oral administration of steroids; six of them were treated in one or two ways. Ocular inflammations were refractory to topical steroid drops. Local steroid injections often led to transient relief. Oral prednisone was often effective but was difficult to taper without inducing flares (Table 5).

Due to serious complications, some of the patients underwent surgery. Patient number 1 underwent a corneal gluing procedure of the right eye [8]. Patient number 2 received bilateral implantation of fluocinolone acetonide intravitreal implants [10]. Patient number 4 received cataract surgery with intraocular lens (IOL) implantation in both eyes and vitrectomy in her right eye [11]. Patient number 6 underwent cataract extraction [12]. Finally, patient number 9 underwent cataract extraction with IOL implantation [12].

3.4. JAK Inhibitor Treatment. No matter which type of JAK inhibitor was used, all of the case reports, except for patient number 8 [12], showed good efficacy with regard to ocular symptoms. Irrespective of whether a patient received monotherapy or combined treatment, almost all gained some form of control over their condition. With regard to systemic 


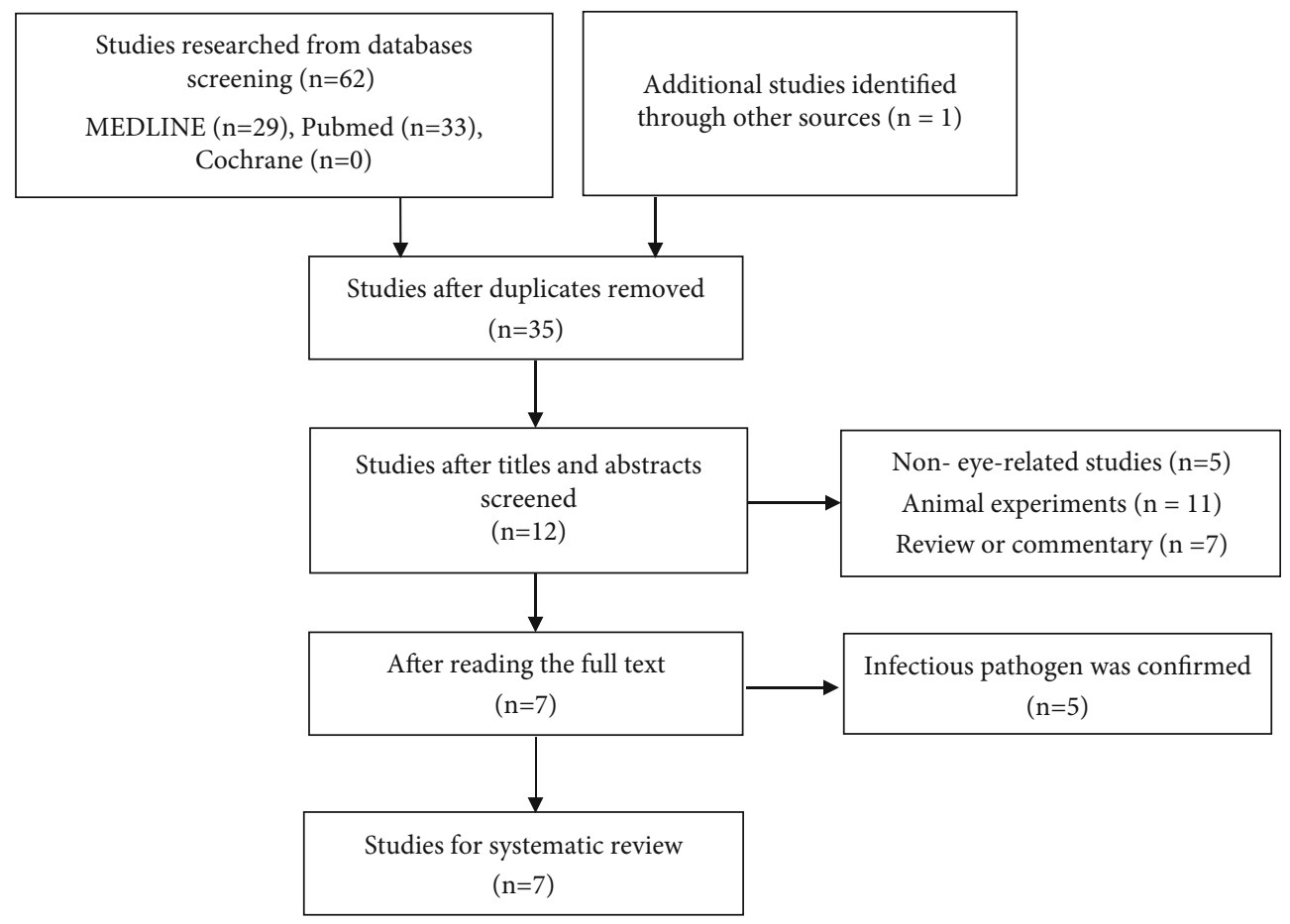

FIGURE 1: The flow diagram of the reviewed literature.

TABLE 1: Features of the case reports included in the analysis.

\begin{tabular}{|c|c|c|c|c|c|c|c|}
\hline Author & Year & Country & Type & Number & Systemic disease & Eye involvement & Intervation \\
\hline Philip B Meadow [8] & 2014 & America & Case report & 1 & RA & Keratitis & Tofacitinib \\
\hline Stephanie Sarny [9] & 2018 & Austria & Case report & 1 & Psoriasis, MMP & Conjunctivitis & Baricitinib \\
\hline Michael A. Paley [10] & 2019 & America & Case report & 2 & NA & Uveitis scleritis & Tofacitinib \\
\hline P. Bauermann [11] & 2019 & Germany & Case report & 1 & JIA & Uveitis & Tofacitinib \\
\hline Elisabetta Miserocchi [12] & 2020 & Italy & Case series & 4 & JIA & Uveitis & $\begin{array}{l}\text { Baricitinib } \\
\text { Tofacitinib }\end{array}$ \\
\hline Richa Pyare [13] & 2020 & India & Case report & 1 & NA & Scleritis & Tofacitinib \\
\hline Claudia Fabiani [14] & 2020 & Italy & Case report & 1 & RA & Scleritis & Tofacitinib \\
\hline
\end{tabular}

JIA: juvenile idiopathic arthritis; RA: rheumatoid arthritis; MMP: mucous membrane pemphigoid; PsA: psoriatic arthritis; NA: not available.

symptoms, the combination of baricitinib with MTX and prednisone still showed an incomplete treatment response with relapsing episodes of active joint inflammation. While taking tofacitinib, none of the reported systemic symptoms were active. The available literature suggests that it might be easier to control systemic symptoms. In some case reports, the response to tofacitinib treatment was rapid; inflammation was usually resolved within one or two weeks (Table 6).

Literature analysis showed that side effects were rare. Only patient number 11 experienced a low level of neutrophil granulocytes during treatment involving baricitinib and MTX [9]. This led to the discontinuation of baricitinib for 2 weeks; subsequently, the patient did not experience any adverse effects. However, we cannot rule out the potential adverse effects of MTX (Table 6).

Some of the literature described the use of JAK inhibitors to treat patients with uveitis and scleritis; the grading of the anterior chamber cells decreased from pretreatment to posttreatment. Other ocular indicators, including best corrected visual acuity and central foveal thickness, showed obvious improvements (Table 7).

\section{Discussion}

The eyeball is composed of different layers and has a separated immune environment. Multiple mechanisms contribute to local immune tolerance, including the absence of vessels in the cornea and the anterior chamber, immunosuppressive factors, and inflammatory regulation via the anterior chamber [16]. The posterior segment of the eye is also a unique structure that contains photoreceptor cells and retinal pigment epithelium; this forms a physical barrier that separates the systemic immune system from the retinal space [17]. However, inflammatory rheumatic diseases can affect multilayer structures and have destructive effects on the 
TABLE 2: Demographic and clinical features of patients.

\begin{tabular}{|c|c|c|c|c|c|c|c|}
\hline Patient & Author & Gender & Age & $\begin{array}{l}\text { Ocular } \\
\text { inflammation }\end{array}$ & Detail of ocluar inflammation & $\begin{array}{l}\text { Systematic } \\
\text { disease }\end{array}$ & $\begin{array}{l}\text { Disease } \\
\text { duration }\end{array}$ \\
\hline 1 & $\begin{array}{l}\text { Philip B. } \\
\text { meadow }\end{array}$ & Female & 59 & Keratitis & $\begin{array}{l}\text { Unilateral ulcerative keratitis (right eye), injection of the } \\
\text { conjunctiva, pericentral ulceration of the cornea,stromal } \\
\text { thinning, pannus, punctate epithelial erosion }\end{array}$ & RA & 9 years \\
\hline 2 & Michael A. & Female & 45 & $\begin{array}{l}\text { Anterior and } \\
\text { intermediate } \\
\text { uveitis }\end{array}$ & $\begin{array}{l}\text { Bilateral anterior uveitis with hypopyon, Vitritis, cystoid } \\
\text { macular edema }\end{array}$ & Undefined & NA \\
\hline 3 & Michael A. & Female & 40 & Scleritis & Bilateral scleritis & NA & NA \\
\hline 4 & $\begin{array}{c}\text { P. } \\
\text { Bauermann }\end{array}$ & Female & 22 & $\begin{array}{l}\text { Anterior } \\
\text { uveitis }\end{array}$ & Bilateral anterior uveitis with macular edema & $\begin{array}{l}\text { JIA(oligo- } \\
\text { extended) }\end{array}$ & 20years \\
\hline 5 & $\begin{array}{l}\text { Claudia } \\
\text { Fabiani }\end{array}$ & Female & 45 & Scleritis & Bilateral anterior scleritis & RA & NA \\
\hline 6 & $\begin{array}{l}\text { Elisabetta } \\
\text { Miserocchi }\end{array}$ & Female & 43 & Panuveitis & $\begin{array}{l}\text { Bilateral aggressive anterior uveitis; cataract, band } \\
\text { keratopathy, macular edema and retinal vasculitis, } \\
\text { retinal detachment and phthisis bulbi; finally bilateral, } \\
\text { chronic panuveitis }\end{array}$ & $\begin{array}{l}\text { JIA(oligo- } \\
\text { extended) }\end{array}$ & 33year \\
\hline 7 & $\begin{array}{l}\text { Elisabetta } \\
\text { Miserocchi }\end{array}$ & Female & 18 & Panuveitis & $\begin{array}{c}\text { Bilateral anterior uveitis at first; bilateral chronic } \\
\text { panuveitis during follow-up cataract, band keratopathy, } \\
\text { glaucoma }\end{array}$ & JIA(polyarticular) & 17years \\
\hline 8 & $\begin{array}{l}\text { Elisabetta } \\
\text { Miserocchi }\end{array}$ & Female & 37 & $\begin{array}{l}\text { Anterior } \\
\text { uveitis }\end{array}$ & Bilateral anterior uveitis, cataract, band keratopathy & $\begin{array}{l}\text { JIA(oligo- } \\
\text { extended) }\end{array}$ & 34 years \\
\hline 9 & $\begin{array}{l}\text { Elisabetta } \\
\text { Miserocchi }\end{array}$ & Male & 21 & Panuveitis & $\begin{array}{l}\text { Unilateral anterior uveitis(right eye), chronic panuveitis } \\
\text { cataract, band keratopathy, macular edema }\end{array}$ & JIA(polyarticular) & 6years \\
\hline 10 & $\begin{array}{l}\text { Richa } \\
\text { Pyare }\end{array}$ & Male & 65 & Scleritis & $\begin{array}{c}\text { Deep episcleral congestion, active necrotizing scleritis } \\
\text { with immature senile cataract }\end{array}$ & NA & 2years \\
\hline 11 & $\begin{array}{l}\text { Stephanie } \\
\text { Sarny }\end{array}$ & Male & 43 & Conjunctivitis & $\begin{array}{l}\text { Bilateral conjunctivitis, subconjunctival fibrosis, } \\
\text { symblepharon, corneal neovascularization }\end{array}$ & $\begin{array}{l}\text { Psoriasis, mucous } \\
\text { membrane } \\
\text { pemphigoid }\end{array}$ & 8years \\
\hline
\end{tabular}

Note: NA: not available.

TABLE 3: Previous therapy history of conventional DMARDs.

\begin{tabular}{|c|c|c|c|c|c|c|c|c|c|}
\hline Patient & Gender & Age & Ocular inflammation & MTX & CTX & CsA & MMF & LEF & AZA \\
\hline 1 & Female & 59 & Keratitis & + & NA & $\mathrm{NA}$ & NA & NA & NA \\
\hline 2 & Female & 45 & Anterior and intermediate uveitis & + & NA & $\mathrm{NA}$ & + & + & + \\
\hline 3 & Female & 40 & Scleritis & + & + & $\mathrm{NA}$ & + & NA & + \\
\hline 4 & Female & 22 & Anterior uveitis & + & NA & + & + & NA & NA \\
\hline 5 & Female & 45 & Scleritis & NA & NA & $\mathrm{NA}$ & NA & NA & NA \\
\hline 6 & Female & 43 & Panuveitis & $\mathrm{NA}$ & NA & $\mathrm{NA}$ & NA & + & NA \\
\hline 7 & Female & 18 & Panuveitis & + & NA & $\mathrm{NA}$ & $\mathrm{NA}$ & NA & NA \\
\hline 8 & Female & 37 & Anterior uveitis & + & $\mathrm{NA}$ & $\mathrm{NA}$ & NA & NA & + \\
\hline 9 & Male & 21 & Panuveitis & + & NA & + & NA & NA & $\mathrm{NA}$ \\
\hline 10 & Male & 65 & Scleritis & NA & NA & $\mathrm{NA}$ & + & NA & NA \\
\hline 11 & Male & 43 & Conjunctivitis & + & + & NA & + & NA & NA \\
\hline
\end{tabular}

Notes: MTX: methotrexate; CTX: cyclophosphamide; CsA: cyclosporine A; MMF: mycophenolate mofetil; LEF: leflunomide; AZA: azathioprine; NA: not available.

ocular microenvironment. Therefore, inflammatory ophthalmic disorders are a group of heterogeneous inflammatory conditions that affect different anatomical ocular tissues, involving scleritis, keratitis, anterior uveitis, posterior uveitis, and retinal vasculitis; these occur in isolation or in the context of systemic autoimmune diseases. Systemic autoimmune diseases that include ocular involvement are also a group of diverse diseases, including rheumatoid arthritis, juvenile idiopathic arthritis, systemic vasculitis, systemic lupus erythematosus, Behçet's syndrome, and relapsing polychondritis [18].

In this article, we reviewed 5 cases of JIA-associated uveitis, 1 case of RA-associated keratitis, 1 case of RA-associated scleritis, 1 case of psoriasis-associated conjunctivitis, 2 cases 
TABLE 4: Previous therapy history of biological DMARDs.

\begin{tabular}{|c|c|c|c|c|c|c|c|c|c|c|c|}
\hline Patient & Gender & Age & Ocular inflammation & $\mathrm{ADA}$ & IFX & ETN & RTX & GOL & CER & $\mathrm{ABA}$ & TCZ \\
\hline 1 & Female & 59 & Keratitis & NA & NA & NA & NA & NA & NA & + & NA \\
\hline 2 & Female & 45 & Anterior and intermediate uveitis & + & + & NA & NA & NA & + & NA & NA \\
\hline 3 & Female & 40 & Scleritis & NA & NA & NA & NA & NA & NA & NA & NA \\
\hline 4 & Female & 22 & Anterior uveitis & + & + & NA & + & + & NA & NA & + \\
\hline 5 & Female & 45 & Scleritis & + & NA & + & + & NA & NA & NA & + \\
\hline 6 & Female & 43 & Panuveitis & + & + & NA & + & NA & NA & + & + \\
\hline 7 & Female & 18 & Panuveitis & + & + & NA & + & NA & NA & + & NA \\
\hline 8 & Female & 37 & Anterior uveitis & + & + & NA & NA & + & NA & NA & + \\
\hline 9 & Male & 21 & Panuveitis & + & + & + & + & NA & NA & + & + \\
\hline 10 & Male & 65 & Scleritis & NA & NA & NA & NA & NA & NA & NA & NA \\
\hline 11 & Male & 43 & Conjunctivitis & + & NA & NA & + & NA & NA & NA & NA \\
\hline
\end{tabular}

Notes: ADA: adalimumab; IFX: infliximab; ETN: etanercept; RTX: rituximab; GOL: golimumab; CER, certolizumab pegol; ABA: abatacept; TCZ: tocilizumab; NA: not available.

TABle 5: Previous therapy history of corticosteroids.

\begin{tabular}{|c|c|c|c|c|c|c|c|c|}
\hline Patient & Gender & Age & Ocular inflammation & Corticosteroid & Dosage & Topical & $\begin{array}{c}\text { Local } \\
\text { Injection }\end{array}$ & Oral \\
\hline 1 & Female & 59 & Keratitis & $\begin{array}{l}\text { Methylprednisolone } \\
\text { Prednisoneacetate }\end{array}$ & Prednisoneacetate $1 \% 1$ drop tid & + & NA & $\mathrm{NA}$ \\
\hline 2 & Female & 45 & $\begin{array}{c}\text { Anterior and intermediate } \\
\text { uveitis }\end{array}$ & Prednisone & $80 \mathrm{mg}$ bid & + & + & + \\
\hline 3 & Female & 40 & Scleritis & Prednisone & $12 \mathrm{mg} \mathrm{qd}$ & + & + & + \\
\hline 4 & Female & 22 & Anterior uveitis & Dexamethasone & 700ug & NA & + & NA \\
\hline 5 & Female & 45 & Scleritis & NA & NA & NA & NA & NA \\
\hline 6 & Female & 43 & Panuveitis & NA & NA & NA & NA & NA \\
\hline 7 & Female & 18 & Panuveitis & Prednisone & $12.5 \mathrm{mg} \mathrm{qd}$ & + & + & + \\
\hline 8 & Female & 37 & Anterior uveitis & NA & NA & NA & + & NA \\
\hline 9 & Male & 21 & Panuveitis & Steroids & NA & NA & + & + \\
\hline 10 & Male & 65 & Scleritis & Prednisolone & $1 \mathrm{mg} / \mathrm{kg} \mathrm{qd}$ & + & NA & + \\
\hline 11 & Male & 43 & Conjunctivitis & Prednisone & NA & NA & NA & + \\
\hline
\end{tabular}

Note: NA: not available.

of noninfectious scleritis, and 1 case of uveitis with suspected autoimmune disease.

Our results are consistent with other reports. JIAassociated uveitis is the most common rheumatic ocular involvement in pediatric patients [19]. The estimated prevalence of uveitis in patients with JIA ranges from 11.6\% [20] to $30 \%$ [21]. The most common form was chronic anterior uveitis, as defined by the classification scheme published by the Standardization of Uveitis Nomenclature (SUN) Working Group $[15,22]$. In a retrospective review, $68.3 \%$ of 1081 JIA cases were shown to have chronic anterior uveitis [23]. Acute anterior uveitis accounted for $16.2 \%$, recurrent anterior uveitis reached $12 \%$, and panuveitis was just $3.5 \%$ [23]. Of the multiple etiological factors responsible for noninfectious scleritis, RA represents a major cause [24]. The anterior segment is more commonly affected than the posterior segment in RA-related ocular complications. In a previous study of 243 patients with scleritis, the most frequent rheumatic disease was RA (15.2\%) [25]. In other studies, RA-related scleritis accounted for approximately $25 \%$ of all cases [26]. RA-related keratitis is also common in patients with active scleritis [18]. However, compared with spondyloarthritis, RA is a rare cause of uveitis [27]. Ophthalmic manifestations are estimated to occur in $10 \%$ of patients with psoriasis and $31 \%$ of patients with psoriatic arthritis (PsA) [28]. Another study reported that the leading ocular disorder in PsA patients was conjunctivitis (19.6\%), followed by iritis $(7.1 \%)$ [29].

Our review of the literature revealed that most of these cases received treatments that included glucocorticoids, several conventional disease-modifying antirheumatic drugs, and multiple biological agents. However, patients did not show adequate improvements or achieve longterm resolutions; they even presented with obvious side effects and faced dilemmas as to whether to continue treatment or not. The statuses of the ocular and systematic 
TABLE 6: Characteristics of JAK inhibitor treatment.

\begin{tabular}{|c|c|c|c|c|c|c|c|c|c|c|}
\hline Patient & Gender & Age & Ocular inflammation & Inhibitor & Dosage & $\begin{array}{c}\text { Treatment } \\
\text { duration }\end{array}$ & $\begin{array}{c}\text { Combined } \\
\text { therapy }\end{array}$ & $\begin{array}{l}\text { Side } \\
\text { effects }\end{array}$ & $\begin{array}{l}\text { Systematic } \\
\text { symptoms }\end{array}$ & $\begin{array}{c}\text { Ocular } \\
\text { symptoms }\end{array}$ \\
\hline 1 & Female & 59 & Keratitis & Tofacitinib & $\begin{array}{l}5 \mathrm{mg} \\
\text { bid }\end{array}$ & $\begin{array}{l}1 \text { month; } \\
\text { Improved after } \\
2 \text { weeks }\end{array}$ & NA & No & Inactive & Inactive \\
\hline 2 & Female & 45 & $\begin{array}{c}\text { Anterior and } \\
\text { intermediate uveitis }\end{array}$ & Tofacitinib & $\begin{array}{l}11 \mathrm{mg} \\
\text { daily }\end{array}$ & $\begin{array}{l}\text { 4months; } \\
\text { Improved after } \\
1 \text { month }\end{array}$ & MTX & No & $\begin{array}{l}\text { Combination: } \\
\text { Inactive } \\
\text { Monotherapy: } \\
\text { Active }\end{array}$ & Inactive \\
\hline 3 & Female & 40 & Scleritis & Tofacitinib & $\begin{array}{l}11 \mathrm{mg} \\
\text { daily }\end{array}$ & $\begin{array}{c}9 \text { months; } \\
\text { Improved after } \\
1 \text { week }\end{array}$ & MTX & No & $\begin{array}{l}\text { No systematic } \\
\text { symptoms }\end{array}$ & Inactive \\
\hline 4 & Female & 22 & Anterior uveitis & Tofacitinib & $\begin{array}{l}5 \mathrm{mg} \\
\text { bid }\end{array}$ & 9 months & $\begin{array}{c}\text { MTX } \\
2.5 \mathrm{mg} \text { qod }\end{array}$ & No & NA & Inactive \\
\hline 5 & Female & 45 & Scleritis & Tofacitinib & $\begin{array}{c}5 \mathrm{mg} \\
\text { bid }\end{array}$ & 6 months & $\begin{array}{l}\text { Prednisone } \\
5 \mathrm{mg} \text { qd }\end{array}$ & No & NA & Inactive \\
\hline 6 & Female & 43 & Panuveitis & Tofacitinib & $\begin{array}{l}5 \mathrm{mg} \\
\text { bid }\end{array}$ & 7 months & NA & No & Inactive & Inactive \\
\hline 7 & Female & 18 & Panuveitis & Baricitinib & $\begin{array}{c}4 \mathrm{mg} \\
\mathrm{Qd}\end{array}$ & 5 months & $\begin{array}{c}\text { MTX } \\
15 \text { mg qw } \\
\text { Prednisone } \\
12.5 \text { mg qd }\end{array}$ & No & Active & Inactive \\
\hline 8 & Female & 37 & Anterior uveitis & Baricitinib & $\begin{array}{l}4 \mathrm{mg} \\
\mathrm{qd}\end{array}$ & 13 months & NA & No & Inactive & Active \\
\hline 9 & Male & 21 & Panuveitis & Baricitinib & $\begin{array}{c}4 \mathrm{mg} \\
\mathrm{qd}\end{array}$ & 4 months & $\begin{array}{c}\text { MTX } \\
15 \text { mg qw } \\
\text { Prednisone } \\
7.5 \text { mg qd }\end{array}$ & No & Active & Inactive \\
\hline 10 & Male & 65 & Scleritis & Tofacitinib & $\begin{array}{c}5 \mathrm{mg} \\
\text { bid }\end{array}$ & $\begin{array}{l}\text { Improvd after } \\
1 \text { month }\end{array}$ & $\begin{array}{c}\text { MMF } 500 \mathrm{mg} \\
\text { bid } \\
\text { Prednisone } \\
2.5 \mathrm{mg} \text { qod }\end{array}$ & No & $\begin{array}{l}\text { No systematic } \\
\text { symptoms }\end{array}$ & Inactive \\
\hline 11 & Male & 43 & Conjunctivitis & Baricitinib & $\begin{array}{c}4 \mathrm{mg} \\
\mathrm{qd}\end{array}$ & $\begin{array}{l}6 \text { month; } \\
\text { Improvd after } \\
2 \text { weeks }\end{array}$ & $\begin{array}{c}\text { MTX } \\
25 \text { mg qw } \\
\text { Prednisolone } \\
6 \text { mg qd }\end{array}$ & Yes & NA & Inactive \\
\hline
\end{tabular}

Note: NA: not available.

inflammation in most of the patients reviewed were refractory and severe.

A range of JAK inhibitors have been or are being developed, for the treatment of refractory cases and those with various autoimmune diseases, including rheumatoid arthritis, psoriatic arthritis, ulcerative colitis, and ankylosing spondylitis [30-32]. Many of the cytokines involved in autoimmune and inflammatory diseases utilize JAKs and STATs to transduce intracellular signals. JAK inhibitors are less selective than biological inhibitors, can simultaneously block the signaling of multiple cytokine axis, and offer new therapeutic strategies [33]. Whether these inhibitors could simultaneously have therapeutic effects on ocular complications remains unclear. Unfortunately, the review of the literature failed to identify publications involving a large case series or randomized controlled trials. We only identified several case reports that indicated the anti-inflammatory effects of JAK inhibitors on the inflammation caused in a diverse range of ocular tissues by different rheumatic diseases.
It is important that we consider why JAK inhibitors exhibit the potential to play a role in autoimmune-related ocular inflammatory diseases. Dysregulation of the JAKSTAT pathway is known to be associated with the pathogenesis of various inflammatory and autoimmune disorders [33, 34]. The JAK-STAT pathway is known to be important for inflammatory cell regulation, cytokine production, and proinflammatory signal transduction $[6,7]$.

Although the etiology of ocular inflammation has yet to be fully elucidated, it is possible that the JAK/STAT pathway may participate in ocular pathology because this mechanism regulates the differentiation of pathogenic Th1 and Th17 cells. The Th1 and Th17 cell subsets require STAT1 and STAT3 during development and may be the etiological agents responsible for human uveitis and scleritis and experimental autoimmune uveoretinitis [35-37]. In the mouse model of uveitis, inhibition of the JAK/STAT signaling pathway by SOCS1-KIR, which binds to JAK2, could suppress and ameliorate experimental autoimmune uveitis (EAU) 
TABLE 7: Treatment response of ocular inflammation.

\begin{tabular}{|c|c|c|c|c|c|c|}
\hline Patient & Gender & Age & Ocular inflammation & BCVA & ACC & CFT \\
\hline 1 & Female & 59 & Keratitis & $\begin{array}{c}\text { Pre:RE:20/200 LE:20/20 } \\
\text { Post:RE:20/30 }\end{array}$ & Pre:RE0 & NA \\
\hline 2 & Female & 45 & Anterior and intermediate uveitis & NA & $\begin{array}{l}\text { Pre:RE2+ LE2+ } \\
\text { Post: RE0.5+ LE0 }\end{array}$ & NA \\
\hline 3 & Female & 40 & Scleritis & NA & NA & NA \\
\hline 4 & Female & 22 & Anterior uveitis & $\begin{array}{l}\text { Pre:RE20/100 LE20/200 } \\
\text { Post:RE20/25 LE20/32 }\end{array}$ & $\begin{array}{c}\text { Pre:RE3+ LE0+ } \\
\text { Post:RE0 LE0 }\end{array}$ & $\begin{array}{c}\text { Pre: } \\
\text { RE468 LE630 } \\
\text { Post: } \\
\text { RE252 LE254 }\end{array}$ \\
\hline 5 & Female & 45 & Scleritis & NA & NA & NA \\
\hline 6 & Female & 43 & Panuveitis & $\begin{array}{c}\text { Pre:RE:20/40 } \\
\text { LE:No light perception }\end{array}$ & $\begin{array}{l}\text { Pre:2+ } \\
\text { Post:0 }\end{array}$ & $\begin{array}{l}\text { Pre:350 } \\
\text { Post:270 }\end{array}$ \\
\hline 7 & Female & 18 & Panuveitis & Post:RE:20/40 LE:20/200 & $\begin{array}{c}\text { Pre:3+ } \\
\text { Post:0.5+ }\end{array}$ & $\begin{array}{l}\text { Pre:320 } \\
\text { Post:264 }\end{array}$ \\
\hline 8 & Female & 37 & Anterior uveitis & Post:RE: 20/60 LE: 20/60 & $\begin{array}{l}\text { Pre:2+ } \\
\text { Post:0 }\end{array}$ & $\begin{array}{l}\text { Pre: } 450 \\
\text { Post:276 }\end{array}$ \\
\hline 9 & Male & 21 & Panuveitis & Post:RE: $20 / 20$ LE: $20 / 20$ & $\begin{array}{c}\text { Pre:3+ } \\
\text { Post:0.5+ }\end{array}$ & $\begin{array}{l}\text { Pre: } 400 \\
\text { Post:280 }\end{array}$ \\
\hline 10 & Male & 65 & Scleritis & $\begin{array}{l}\text { Pre:RE6/ } 6 \text { LE 6/36 } \\
\text { Post:LE6/24 }\end{array}$ & $\begin{array}{l}\text { Pre:1+ } \\
\text { Post:0 }\end{array}$ & NA \\
\hline 11 & Male & 43 & Conjunctivitis & Pre:RE20/30 LE:Counting fingers & NA & NA \\
\hline
\end{tabular}

Note: ACC: anterior chamber cell; BCVA: best corrected visual acuity; CFT: central foveal thickness: Pre: pretreatment; Post: posttreatment; RE: right eye; LE: left eye; NA: not available.

[38]. The mechanism that is responsible for this action involves downregulating the proliferation of pathogenic Th17 cells and inhibiting the migration of inflammatory cells into the neuroretina during EAU. However, some researchers have reported that the effect of tofacitinib on Th1/Th17 balance in the EAU model was different from the effects induced by SOCS1-KIR. Tofacitinib inhibited the development of EAU by reducing the proportion of Th1 cells instead of Th17 cells, and by suppressing the production of IFN- $\gamma$, did not exert effect on the expression of IL-17 and its transcription factor ROR $\gamma \mathrm{t}$ [39]. JAK inhibitors can control both intraocular inflammation and ocular surface inflammation. In an animal model of experimental dry eye, the application of a topical JAK inhibitor (tofacitinib) suppressed ocular surface inflammation and immunity in an experimental model of corneal thermocautery [40]. Even in the conjunctive structure of ocular tissue, tofacitinib has also been shown to prevent experimental allergic conjunctivitis in $\mathrm{BALB} / \mathrm{c}$ mice by downregulating the phosphorylation of JAK3/STAT signaling [41].

This retrospective review had some limitations that need to be considered, including the lack of a control group, the small number of patients, and the lack of high-level evidence-based studies. However, we believe that all of these cases reported herein are valuable and can facilitate the future direction of our research. Future research may prove that JAK inhibitors can provide a novel treatment option for refractory autoimmune-related ocular inflammation.

\section{Conclusion}

JAK inhibitors may represent an alternative treatment option for patients with autoimmune-related ocular inflammation.

\section{Conflicts of Interest}

None of the authors have any conflicts of interest to declare.

\section{Authors' Contributions}

Ji Wen, Huifang $\mathrm{Hu}$, and Menglin Chen contributed equally to this work.

\section{Acknowledgments}

This project was supported by The Science and Technology Project Of The Health Planning Committee of Sichuan (Project no. 19PJ251) and by 1.3.5 project for disciplines of excellence, West China Hospital, Sichuan University (Project nos. ZYGD18015 and ZYJC18003). The authors would like to express their gratitude to EditSprings (https://www .editsprings.com/) for the expert linguistic services provided.

\section{References}

[1] D. Wakefield, N. di Girolamo, S. Thurau, G. Wildner, and P. McCluskey, "Scleritis: immunopathogenesis and molecular basis for therapy," Progress in Retinal and Eye Research, vol. 35, pp. 44-62, 2013. 
[2] S. Horton, A. P. Jones, C. M. Guly et al., "Adalimumab in juvenile idiopathic arthritis-associated uveitis: 5-year follow-up of the bristol participants of the SYCAMORE trial," American Journal of Ophthalmology, vol. 207, pp. 170-174, 2019.

[3] E. B. Suhler, L. L. Lim, R. M. Beardsley et al., "Rituximab therapy for refractory scleritis: results of a phase I/II dose- ranging, randomized, clinical trial," Ophthalmology, vol. 121, no. 10, pp. 1885-1891, 2014.

[4] V. Dipasquale, M. Atteritano, J. Fresta, I. Castagna, and G. Conti, "Tocilizumab for refractory uveitis associated with juvenile idiopathic arthritis: a report of two cases," Journal of Clinical Pharmacy and Therapeutics, vol. 44, no. 3, pp. 482485, 2019.

[5] A. Ragam, A. M. Kolomeyer, C. Fang, Y. Xu, and D. S. $\mathrm{Chu}$, "Treatment of chronic, noninfectious, nonnecrotizing scleritis with tumor necrosis factor alpha inhibitors," Ocular Immunology and Inflammation, vol. 22, no. 6, pp. 469-477, 2014.

[6] S. H. Liew, K. K. Nichols, K. J. Klamerus, J. Z. Li, M. Zhang, and G. N. Foulks, "Tofacitinib (CP-690,550), a Janus kinase inhibitor for dry eye disease: results from a phase $1 / 2$ trial," Ophthalmology, vol. 119, no. 7, pp. 1328-1335, 2012.

[7] L. J. Scott, "Tofacitinib: a review of its use in adult patients with rheumatoid arthritis," Drugs, vol. 73, no. 8, pp. 857874, 2013

[8] P. B. Meadow, J. Nguyen, and K. Kesavarapu, “Tofacitinib citrate for ulcerative keratitis in a patient with rheumatoid arthritis," Case reports in rheumatology, vol. 2014, Article ID 403452, 3 pages, 2014.

[9] S. Sarny, M. Hucke, and Y. el-Shabrawi, "Treatment of mucous membrane pemphigoid with Janus kinase inhibitor baricitinib," JAMA ophthalmology, vol. 136, no. 12, pp. 1420-1422, 2018.

[10] M. A. Paley, H. Karacal, P. K. Rao, T. P. Margolis, and J. J. Miner, "Tofacitinib for refractory uveitis and scleritis," American journal of ophthalmology case reports, vol. 13, pp. 53-55, 2019.

[11] P. Bauermann, A. Heiligenhaus, and C. Heinz, "Effect of Janus kinase inhibitor treatment on anterior uveitis and associated macular edema in an adult patient with juvenile idiopathic arthritis," Ocular Immunology and Inflammation, vol. 27, no. 8, pp. 1232-1234, 2019.

[12] E. Miserocchi, C. Giuffrè, M. Cornalba, I. Pontikaki, and R. Cimaz, "JAK inhibitors in refractory juvenile idiopathic arthritis-associated uveitis," Clinical Rheumatology, vol. 39, no. 3, pp. 847-851, 2020.

[13] R. Pyare, V. Kaushik, P. Dutta Majumder, and J. Biswas, "Tofacitinib in recalcitrant scleritis: first case report from India," Indian Journal of Ophthalmology, vol. 68, no. 9, pp. 19881990, 2020.

[14] C. Fabiani, J. Sota, M. Sainz-de-la-Maza et al., "New potential weapons for refractory scleritis in the era of targeted therapy," Mediators of Inflammation, vol. 2020, Article ID 8294560, 6 pages, 2020.

[15] D. A. Jabs, R. B. Nussenblatt, and J. T. Rosenbaum, "Standardization of uveitis nomenclature for reporting clinical data. Results of the first international workshop," American Journal of Ophthalmology, vol. 140, no. 3, pp. 509-516, 2005.

[16] E. Generali, L. Cantarini, and C. Selmi, "Ocular involvement in systemic autoimmune diseases," Clinical Reviews in Allergy and Immunology, vol. 49, no. 3, pp. 263-270, 2015.
[17] V. L. Perez, A. M. Saeed, Y. Tan, M. Urbieta, and F. Cruz-Guilloty, "The eye: a window to the soul of the immune system," Journal of Autoimmunity, vol. 45, pp. 7-14, 2013.

[18] P. McCluskey and R. J. Powell, "The eye in systemic inflammatory diseases," Lancet, vol. 364, no. 9451, pp. 2125-2133, 2004.

[19] J. A. Smith, F. Mackensen, H. N. Sen et al., "Epidemiology and course of disease in childhood uveitis," Ophthalmology, vol. 116, no. 8, pp. 1544-1551.e1, 2009.

[20] S. T. Angeles-Han, C. F. Pelajo, L. B. Vogler et al., "Risk markers of juvenile idiopathic arthritis-associated uveitis in the Childhood Arthritis and Rheumatology Research Alliance (CARRA) Registry," The Journal of Rheumatology, vol. 40, no. 12, pp. 2088-2096, 2013.

[21] A. Moradi, R. M. Amin, and J. E. Thorne, "The role of gender in juvenile idiopathic arthritis-associated uveitis," Journal of Ophthalmology, vol. 2014, Article ID 461078, 7 pages, 2014.

[22] E. S. Sen and A. V. Ramanan, "Juvenile idiopathic arthritisassociated uveitis," Clinical Immunology, vol. 211, article 108322, 2020.

[23] K. Sabri, R. K. Saurenmann, E. D. Silverman, and A. V. Levin, "Course, complications, and outcome of juvenile arthritisrelated uveitis," Journal of AAPOS, vol. 12, no. 6, pp. 539545,2008

[24] L. Tong, J. Thumboo, Y. K. Tan, T. Y. Wong, and S. Albani, "The eye: a window of opportunity in rheumatoid arthritis?," Nature Reviews Rheumatology, vol. 10, no. 9, pp. 552-560, 2014.

[25] E. K. Akpek, J. E. Thorne, F. A. Qazi, D. V. Do, and D. A. Jabs, "Evaluation of patients with scleritis for systemic disease," Ophthalmology, vol. 111, no. 3, pp. 501-506, 2004.

[26] M. Artifoni, P. R. Rothschild, A. Brézin, L. Guillevin, and X. Puéchal, "Ocular inflammatory diseases associated with rheumatoid arthritis," Nature Reviews Rheumatology, vol. 10, no. 2, pp. 108-116, 2014.

[27] P. Sève, L. Kodjikian, L. Adélaïde, and Y. Jamilloux, "Uveitis in adults: what do rheumatologists need to know?," Joint, Bone, Spine, vol. 82, no. 5, pp. 308-314, 2015.

[28] B. Rehal, B. S. Modjtahedi, L. S. Morse, I. R. Schwab, and H. I. Maibach, "Ocular psoriasis," Journal of the American Academy of Dermatology, vol. 65, no. 6, pp. 1202-1212, 2011.

[29] J. R. Lambert and V. Wright, "Eye inflammation in psoriatic arthritis," Annals of the Rheumatic Diseases, vol. 35, no. 4, pp. 354-356, 1976.

[30] for the Pediatric Rheumatology International Trials Organization (PRINTO), the Pediatric Rheumatology Collaborative Study Group (PRCSG), N. Ruperto et al., "Pharmacokinetic and safety profile of tofacitinib in children with polyarticular course juvenile idiopathic arthritis: results of a phase 1, open-label, multicenter study," Pediatric Rheumatology Online Journal, vol. 15, no. 1, p. 86, 2017.

[31] M. Harigai, "Growing evidence of the safety of JAK inhibitors in patients with rheumatoid arthritis," Rheumatology (Oxford), vol. 58, Supplement_1, pp. i34-i42, 2019.

[32] H. Abdulrahim, H. Sharlala, and A. O. Adebajo, "An evaluation of tofacitinib for the treatment of psoriatic arthritis," Expert Opinion on Pharmacotherapy, vol. 20, no. 16, pp. 1953-1960, 2019.

[33] H. You, D. Xu, J. Zhao et al., "JAK inhibitors: prospects in connective tissue diseases," Clinical Reviews in Allergy and Immunology, vol. 59, no. 3, pp. 334-351, 2020.

[34] S. Banerjee, A. Biehl, M. Gadina, S. Hasni, and D. M. Schwartz, "JAK-STAT signaling as a target for inflammatory and 
autoimmune diseases: current and future prospects," Drugs, vol. 77, no. 5, pp. 521-546, 2017.

[35] D. Luger, P. B. Silver, J. Tang et al., "Either a Th17 or a Th1 effector response can drive autoimmunity: conditions of disease induction affect dominant effector category," The Journal of Experimental Medicine, vol. 205, no. 4, pp. 799-810, 2008.

[36] A. Amadi-Obi, C. R. Yu, X. Liu et al., " $\mathrm{T}_{\mathrm{H}} 17$ cells contribute to uveitis and scleritis and are expanded by IL-2 and inhibited by IL-27/STAT1," Nature Medicine, vol. 13, no. 6, pp. 711-718, 2007.

[37] X. Liu, Y. S. Lee, C. R. Yu, and C. E. Egwuagu, "Loss of STAT3 in CD4+ T cells prevents development of experimental autoimmune diseases," Journal of Immunology, vol. 180, no. 9, pp. 6070-6076, 2008.

[38] C. He, C. R. Yu, L. Sun, R. M. Mahdi, J. Larkin III, and C. E. Egwuagu, "Topical administration of a suppressor of cytokine signaling-1 (SOCS1) mimetic peptide inhibits ocular inflammation and mitigates ocular pathology during mouse uveitis," Journal of Autoimmunity, vol. 62, pp. 31-38, 2015.

[39] S. J. Bing, C. Lyu, B. Xu et al., "Tofacitinib inhibits the development of experimental autoimmune uveitis and reduces the proportions of Th1 but not of Th17 cells," Molecular Vision, vol. 26, pp. 641-651, 2020.

[40] W. Stevenson, Z. Sadrai, J. Hua et al., "Effects of topical Janus kinase inhibition on ocular surface inflammation and immunity," Cornea, vol. 33, no. 2, pp. 177-183, 2014.

[41] Y. Li, X. Liu, J. Yu et al., "Tofacitinib suppresses mast cell degranulation and attenuates experimental allergic conjunctivitis," International Immunopharmacology, vol. 86, article 106737, 2020. 